\title{
SIR PATRICK MANSON: PHYSICIAN TO THE COLONIAL OFFICE, 1897-1912
}

\author{
by
}

\section{ELI CHERNIN *}

In 1897 Joseph Chamberlain, Secretary of State for the Colonies, appointed Patrick Manson (1844-1922) Medical Adviser to the Colonial Office. ${ }^{1}$ Manson's assumption of that post opened the last fifteen years of his already notable professional life. His primary charge as Medical Adviser was not, as is commonly thought, to advise on policy matters; Manson's main, if somewhat less exalted, responsibility was to examine for medical fitness candidates for the Colonial Service, and to attend those invalided home. This important but little-known aspect of Manson's Colonial Office work is the subject of the present study.

\section{BACKGROUND}

Manson spent several years in Formosa after completing medical training in 1866 in Aberdeen, and he then served as Medical Officer (1871-83) to the British-run Chinese Imperial Maritime Customs Service in Amoy, a sub-tropical port in South China. His medical work there-for he was, in effect, the "company doctor"-led him to study

* Professor Chernin, of the Department of Tropical Public Health, Harvard School of Public Health, Boston, died in February 1990, before this paper could be published. The Editors would like to thank his daughter, Lisa T. Chernin, and Richard J. Wolfe for their assistance in preparing the paper for publication. Address for correspondence: Lisa T. Chernin, 1332 W. Bell No. 2, Houston, Texas 77019, USA.

\section{ACKNOWLEDGEMENTS}

The research for this report was supported, in part, by a Research Career Award from the National Institutes of Health, Bethesda, Maryland, and by a grant from the Milton Fund of Harvard University. Mr Brian Furner, Librarian, London School of Hygiene and Tropical Medicine, kindly granted permission to publish from the Manson casebooks, and Ms Mary E. Gibson and Mr John Eyers, Assistant Librarians, London School, provided welcome aid and advice. I thank Ms Sue Bramley, Archivist, Wellcome Tropical Institute, London, and Professor E. H. O. Parry, Director of the Institute, for his permission to publish materials from the Institute's Archives. I received helpful guidance from the reference staff of the Public Records Office, Kew, London, from Mr David Paul, Documents Division, Harvard College (Widener) Library, Cambridge, Massachusetts, and from Mr Richard J. Wolfe, Curator of Rare Books, Countway Medical Library, Harvard Medical School, Boston.

I am grateful to Dr Marcello Pagano, Department of Biostatistics, Harvard School of Public Health, for suggesting the sampling method used in the study. The numerical information summarized in Tables 1 and 2 , and in the corresponding section of the text, derive from a computer analysis of the Manson casebook data by my colleague, Dr Jose Ribeiro, Harvard School of Public Health, to whom I extend my thanks.

${ }^{1}$ Joseph Chamberlain (1836-1914) was the father of the half-brothers Austen and Neville Chamberlain, both of whom became prominent political figures in Britain. According to R. L. Sheppard, "Manson's appointment as [Chamberlain's] Medical Adviser was a bold step since he was not then a Fellow of the Royal Society" from which the government usually sought urgent scientific advice ('The bureau and system of abstracting and information services, etc.,' Proc. Brit. Soc. Intl. Biblio., 1943, 5: 83-90). 


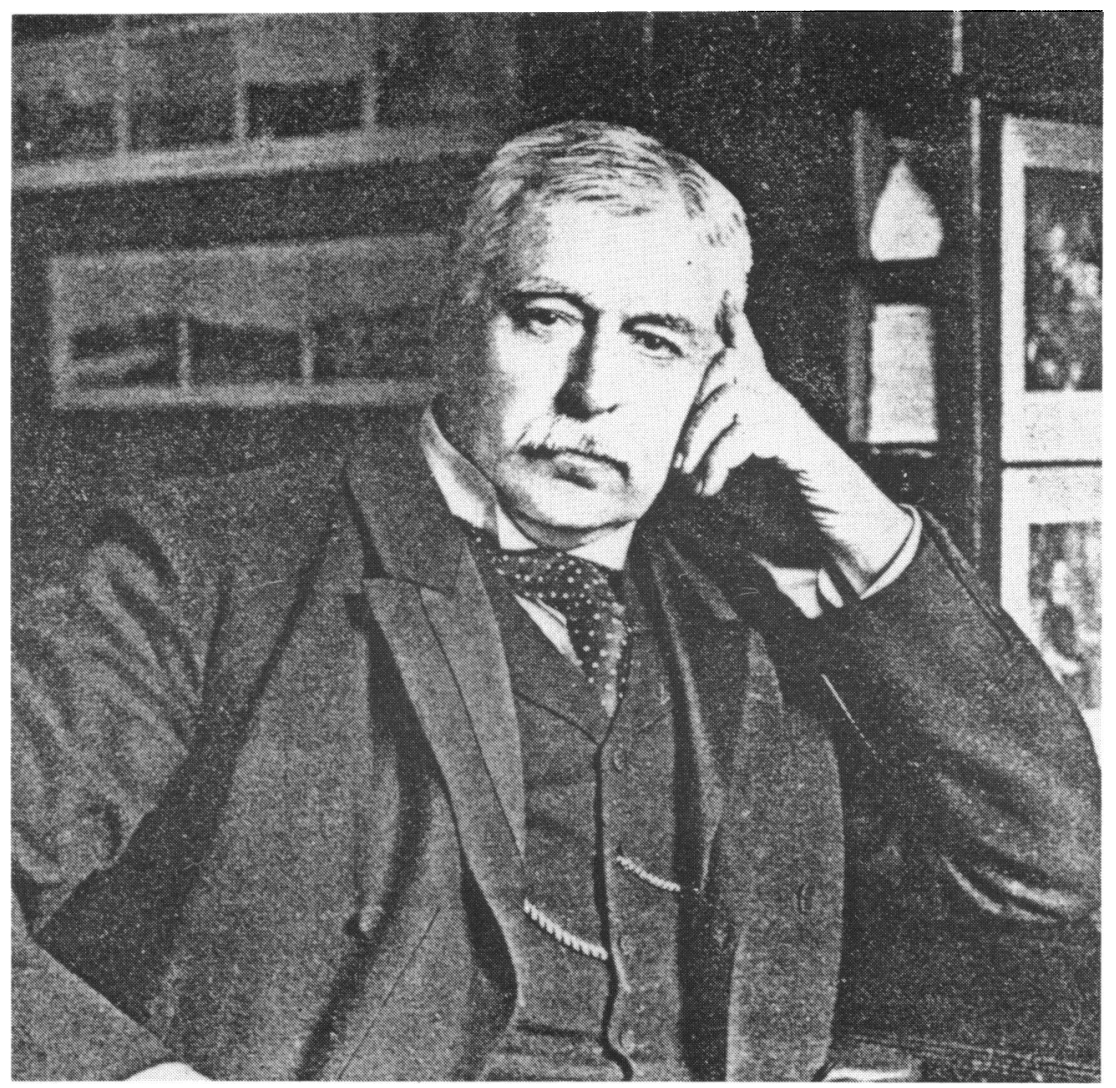

Plate 1 Sir Patrick Manson, circa 1908. 


\section{Sir Patrick Manson}

elephantiasis (filariasis) and to the revolutionary discovery that mosquitoes serve as the intermediaries in transmitting the causal parasite. If one were to ignore all of Manson's later work, this one finding assures him a place alongside the medical greats of modern times.

The years 1883-89 Manson spent in private medical practice in Hong Kong, where he helped found a medical school, a medical society, and a safe dairy farm. He returned to Britain in 1889 and developed a consulting practice based in his home in Queen Anne Street, near London's Cavendish Square. In the 1890s, Manson endorsed the hypothesis that malaria, by analogy with filariasis, might also be mosquito-borne, and, during 1894-98 he encouraged and supported Ronald Ross's researches in India that ultimately proved the hypothesis correct. By then Manson was the established leader of the growing body of British physicians concerned with tropical diseases.

In mid-1897 the post of Medical Adviser to the Colonial Office fell open. Manson applied for and received the appointment, which elevated his own status and gave Chamberlain an expert. Manson's principal biographer wrote that "It was not long before Manson and Chamberlain got down to plans", 2 and that "The close association between the two men ... was destined to be fruitful of great results." 3 While the implied degree of intimacy and influence cannot be substantiated from the archival record, Manson and Chamberlain did collaborate on a range of medical, sanitary and educational matters important to the Colonial Office. These included setting up medical services for West Africa, establishing research laboratories in some of the major colonies, revising, publishing, and circulating the medical reports from the colonies, capitalizing on Ross's mosquito-malaria breakthrough, and, perhaps best known, founding the London School of Tropical Medicine (1899). In all of these initiatives, Chamberlain is said to have been Manson's "firm and great coadjutor", 4 the first English statesman "with imagination enough to apprehend the great part which medical science [plays] in the world", 5 and, in sum, "the greatest Colonial Secretary that Great Britain has ever possessed". 6

\section{MANSON'S APPOINTMENT TO THE COLONIAL OFFICE}

On 28 June 1897 Manson applied for the office of Medical Adviser, summarizing his qualifications and experience in a brief modest letter addressed to the Under Secretary of State: ${ }^{7}$

Sir,

I have the honour to apply for the appointment of Physician and Medical Adviser to the Colonial Office and Crown Agents of the Colonies, vacated, or about to be vacated by Sir Chas. Gage Brown.

\footnotetext{
${ }^{2}$ P. Manson-Bahr, Patrick Manson, London, Thomas Nelson and Sons, 1962, p. 115.

${ }^{3}$ P. Manson-Bahr and A. Alcock, The life and work of Sir Patrick Manson, New York, William Wood, 1927 , p. 116.

4 P. Manson-Bahr, 'Patrick Manson (1844-1922)', Chapter 21, pp. 194-206, in D'Arcy Power (ed.), British masters of medicine, London, Medical Press and Circular, 1936, p. 203.

${ }_{5}^{5}$ T. Clifford Allbutt, The historical relations of medicine and surgery, London, Macmillan, 1905, p. 3.

${ }^{6}$ Manson-Bahr, op. cit., note 4 above, p. 203.

${ }^{7}$ Manson to Sir E[dward] Wingfield [Permanent Under Secretary], 28 June 1897, Colonial Office 323/425/14027, pp. 344-5. Bibliographic note: Archival materials from the Colonial Office are henceforth
} 


\section{Eli Chernin}

I am 52 years of age, a Doctor of Medicine of the University of Aberdeen and a Fellow of the Royal College of Physicians of London. I am also L.L.D. of the University of Aberdeen.

In furtherance of my application I beg to state that I have had large experience in tropical and colonial disease. I practised my profession in China (Formosa, Amoy, Hongkong) for over 23 years and while abroad held many public appointments, including the Medical Officership to H.B.M.'s Consulates in Taiwan and Amoy. I had also large hospitals under my charge. Since my return to England in 1889 I have been engaged in consulting practise in London, especially in connection with tropical disease.

I am physician to the Seamen's Hospital (Albert Dock Branch) and lecturer on Tropical Diseases at St. George's Hospital and Charing Cross Hospital Medical Schools.

During the whole of my professional life I have made a special study of tropical disease, and have contributed largely to the literature of the subject and, perhaps, something to the science.

On these grounds I venture to make this application. I have only today heard that the appointment is to be vacated and filled immediately; otherwise I should have been pleased to enclose testimonials from many of the leaders of the profession. I have however Sir Joseph Fayrer's and Sir William Broadbent's permission to refer to them as to my fitness for the position.

I have the honour to be, [etc.]

John Bramston (later Sir John), the Assistant Permanent Under Secretary of State, informed Manson of his selection as Medical Adviser on 14 July 1897. Bramston's letter laid out explicitly that Manson was to examine persons for Colonial appointment, and it specified his fee for service, but it said nothing about wanting or expecting Manson's advice on matters beyond his consulting room: ${ }^{8}$

Sir,

In reply to your letter of the 28th June I am directed by Mr. Secretary Chamberlain to acquaint you that he has selected you to medically examine, on behalf of this Department in London, Colonial Officers and candidates for Colonial employment, and I am to request to be informed of your hours for consultation in Queen Anne Street.

Every person sent to you by this Department for medical examination will, in the absence of any special letter addressed to you direct, be furnished with one or other of the accompanying forms of letter, which indicate by whom your fees will be paid.

It would be convenient if you would send in to this Department periodically, a list of the persons examined in cases where the fee is payable by Government, in order that the Crown Agents for the Colonies may be instructed to pay you the amount due by the various Colonial Governments in one lump sum.

It is understood that the fee for each examination is one guinea, except in the case of consultations which have been specially authorised by the Secretary of State.

It is assumed that you will be prepared to assume the work of examination on Monday the 19th inst.

I am, Sir [etc.]

designated "CO", followed by the file number. The Colonial Office records are conserved in the Public
Records Office, Kew, London.
8 John Bramston to Manson, 14 July 1897 , Wellcome Tropical Institute, Archive file 2(19). The matter of
money bears some comment. Manson received no income for his policy-advice to the Colonial Office; he 


\section{Sir Patrick Manson}

Manson acknowledged Bramston's letter, repeating the understanding that "Mr. Secretary Chamberlain ha[s] selected me to medically examine on behalf of his Department in London, Colonial Officers and candidates for Colonial appointment." The rest of Manson's brief response dealt with his consulting hours. As requested, Manson was ready for work on 19 July, barely three weeks after he applied for the post. ${ }^{9}$

On 15 October 1897, three months after his appointment, Manson followed up on a conversation with the Under Secretary of State by providing him with written suggestions on various matters: that expanded academic and clinical training in tropical medicine was needed; that preference should be given for overseas appointment to medical candidates trained in tropical medicine; and that medical reports from the colonies should be modified, simplified, and the consolidated data published and circulated. ${ }^{10}$ The burden of Manson's letter clearly went beyond the role of "medical examiner" stipulated when he signed on. This turn of direction became more explicit in December 1897 when Manson responded to Chamberlain's request for his "observations and suggestions" with an eleven-page letter analysing (among other things) the need for a special Commission to oversee anti-malaria measures in West Africa. ${ }^{11}$ It is not apparent how Manson and Chamberlain transformed part of the Medical Adviser's post from that of a consultant clinician to that of a medical statesman, but there is no doubt that Manson enjoyed Chamberlain's support. Manson apparently saw himself as a militant, doubtless with his own private agenda, in the cause of Chamberlain's "constructive imperialism", which was aimed at exploiting Britain's tropical "undeveloped estates". 12

Manson's basic job with the Colonial Office remained that of physician, and he dealt with policy matters ad hoc. For better perspective I digress to note that Manson was not the first or indeed the only Medical Adviser to the Colonial Office; he had, it will be recalled, succeeded Sir Charles Gage Brown who served as Medical Adviser for some fifteen years but who, it appears, was not greatly involved in broad policy matters. Furthermore, during his own fifteen-year term, Manson was not the Medical Adviser to the Colonial Office since others held the same title concurrently: Dr Andrew

\footnotetext{
did however receive the stipulated fee of one guinea, i.e., twenty-one shillings, for each medical examination (as did his successors after he retired in 1912). At a rough calculation based on his patient load, this would have brought Manson about $£ 1,000$ annually, a very large amount for (say) 1900 , and equal to about $£ 42,000(\$ 71,000)$ in 1985 purchasing power. Manson also received income from his private practice and from book royalties; at his death in 1922 he left an estate of $£ 57,300$ (The Times, 14 June 1922, p. 13e).

${ }^{9}$ Manson to the Under Secretary of State, 15 July 1897, CO 323/425/15343, p. 377.

${ }^{10}$ Manson to the Under Secretary of State, 15 October 1897, CO/323/425/22442, pp. 392-5. While speculative, the idea of circulating to all the colonies the collected medical reports may have originated in Manson's experience with the Medical reports of the China Imperial Medical Customs, first published in 1871, in which Customs Medical Officers (of whom Manson was one) were encouraged to publish on conditions in their territories for the information of all (E. Chernin, 'Sir Patrick Manson's studies on the transmission and biology of filariasis', Rev. inf. Dis., 1983, 5: 148-66).

${ }_{11}$ Manson to the Under Secretary of State, 4 December 1897, Wellcome Tropical Institute, Archive File 2(19). This letter is of malariological interest because, in writing only eight months before Ross confirmed Manson's own mosquito-malaria hypothesis, Manson described in great detail how to protect colonials and their houses from the malarious miasmas that were said to arise from soil and water.

12 M. Worboys, 'The emergence of tropical medicine: a study in the establishment of a scientific specialty', p. 83 in G. Lemaine (ed.), Perspectives on the emergence of scientific disciplines, The Hague, Mouton, 1976.
} 


\section{Eli Chernin}

Davidson (succeeded by Lt.-Col. James Arnott in 1907) in Edinburgh, and Dr J. Hawtrey Benson in Dublin. ${ }^{13}$ All were respected clinicians, but none apparently served the Colonial Office in a policy capacity analogous to Manson's. ${ }^{14}$

\section{MANSON AS PHYSICIAN TO THE COLONIAL OFFICE}

Records have come to light of Manson's clinical work, their beginnings dating from a letter Manson sent to the Colonial Office on 15 October $1897^{15}$ in which he suggested to the Secretary "... that the notes of the physical examinations of candidates for employment in the Colonial Service and of members of the service, made by the Medical Adviser of the Colonial Government, should be kept according to a special form, in a special book. ..." Manson's remark about record books led to my finding them in the Rare Book Room, Library, London School of Hygiene and Tropical Medicine. ${ }^{16}$ The bound volumes, indistinctly stamped Medical Examinations in Connection with the Colonies and Protectorates, each contain about 400 oversized comprehensive record forms printed on heavy stock, with entries in Manson's hand (see fig.). Except that the first two volumes of the set are missing (roughly, late 1897 to mid-1898), the Manson series is intact to volume 25 (1912), which marks the end of his office. (The series continues down to volume 32, 1918, under C. W. Daniels, one of Manson's successors.)

In response to an inquiry in 1910 from Lord Crewe, then Secretary of State, about the status and availability of medical records, Manson replied that he had twenty volumes-about 10,000 records-of Colonial Office examinations. He considered the clinical material valuable and had hoped to summarize the mass of data, but the task seemed too heavy for the time remaining at his disposal. ${ }^{17}$ Manson suggested to Crewe that the Colonial Office appoint a committee, including a medically qualified full-time secretary, to summarize and analyse his data (which grew even larger with the volumes for the final two years of Manson's tenure). The data also included entries on illnesses acquired in the Colonies by returnees, that Manson entered on the blank reverse of individual records. Manson's good opinion about the worth of his records is counterbalanced by the fact that his handwriting is difficult to decipher and that it grew worse with age.

The following summary of Manson's medical records is based on a sample of 500 out of about 12,000 records: 50 consecutive records were abstracted selectively, on standard forms, from blind starts in each of 10 volumes (roughly every other volume),

\footnotetext{
13 J. Anderson, Colonial Office list, London, Harrison and Sons, 1912. [Revised and issued annually.]

14 Manson's policy-making activities in the Colonial Office are described, with more or less supportive data, by (among others): Manson-Bahr and Alcock, op. cit., note 3 above; Worboys, op. cit., note 12, above; R. V. Kubicek, The administration of imperialism: Joseph Chamberlain at the Colonial Office, Durham, N.C., Duke University Press, 1969; R. E. Dumett, 'The campaign against malaria and the expansion of scientific medical and sanitary services in British West Africa, 1898-1910', Afr. Hist. Studies, 1968, 1: 153-87.

${ }^{15}$ Manson to the Under Secretary of State, op. cit., note 10 above.

${ }^{16}$ I am indebted to Mr John Eyers, Assistant Librarian, London School of Hygiene and Tropical Medicine, for guiding me to Manson's casebooks when I inquired about their existence. The library had no record of their acquisition or provenance.

${ }^{17}$ Manson to Colonial Office, 2 June 1910, CO 879/102, Medical and sanitary matters in tropical Africa, Confidential Print, Series 940/16586, pp. 276-7.
} 


\section{Sir Patrick Manson}

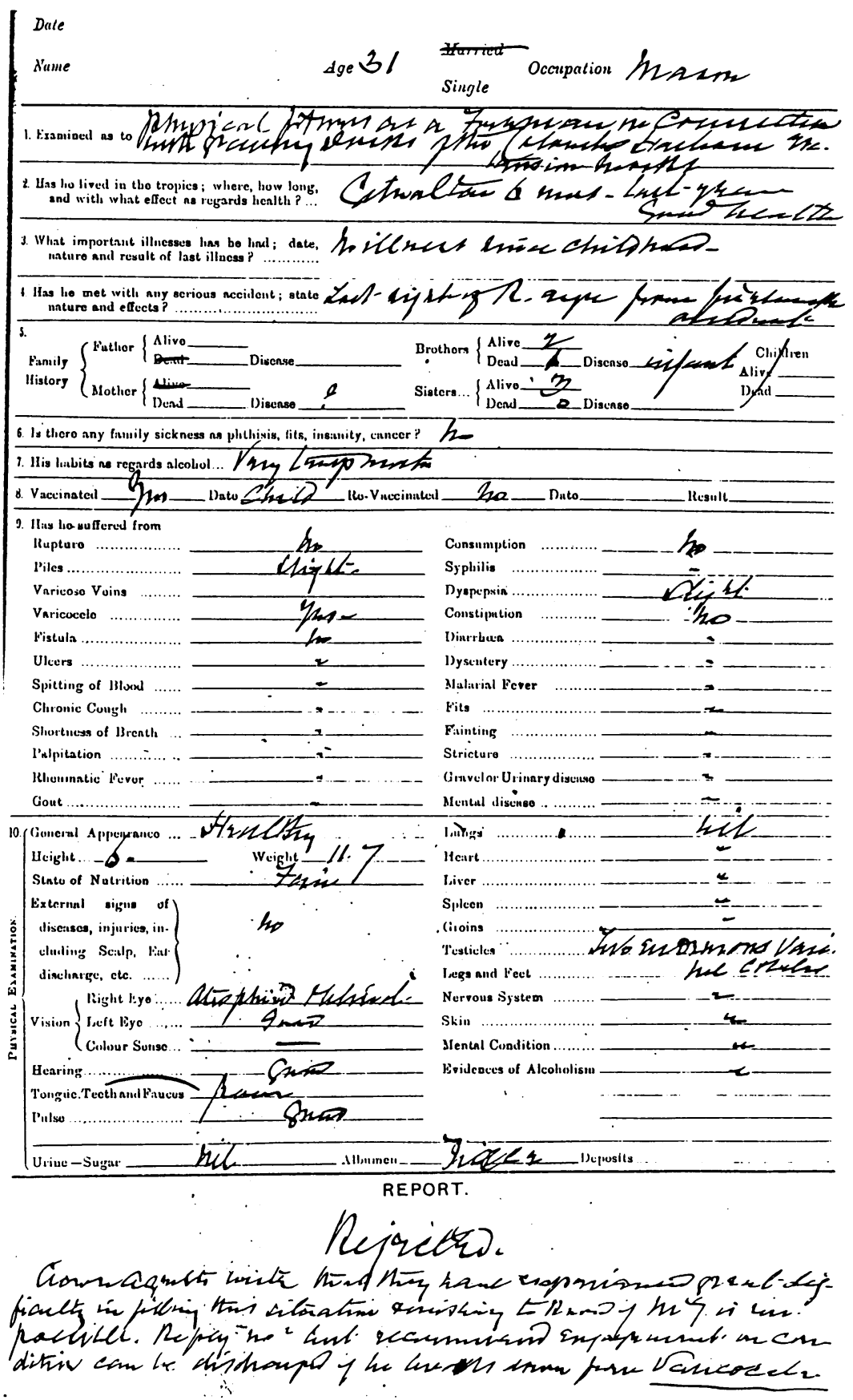

An examination page from Manson's Colonial Office records (reduced to 58 percent of original $20 \times 33 \mathrm{~cm}$ size). The entries are in Manson's handwriting, and the form is one he used throughout his tenure in the Office. The date, page number, and examinee's name have been deleted to preserve anonymity. Page reproduced by permission of Mr Brian Furner, Librarian, London School of Hygiene and Tropical Medicine. 


\section{Eli Chernin}

spanning 1898-1911. The data were subjected to computer analysis which disclosed, among other things, that the 500 examinations - each perhaps taking 45 minutesinvolved Manson on 228 work-days during which he saw an average of 2.2 examinees (range 1-10) per day. Of the 500, 413 (82.6 per cent) were new applicants for the Colonial Service posts, and 82 (16.4 per cent) were Service personnel returning from the tropics. (Such data for 5 persons (1 per cent) are missing.) Over the years, Manson saw 149 (29.6 per cent) of the sample population more than once.

Further analysis was aimed at characterizing those who came through Manson's consulting-room door. Not unexpectedly, the majority were men (465; 93 per cent) mostly under 35 years of age $(18-24=55 ; 25-29=155 ; 30-34=155 ; 35-39=89$; $40-44=27 ; 45-58=23$; not recorded $=3$ ). The average age of the new applicants was 30.7 years (range 18-56), while the returnees averaged five years older $(35.6$, range 23-55).

Considered by occupation, the four largest groups were engineers, railway workers, medical and nursing personnel, and administrators, and the rest ranged from labourers to barristers (Appendix, Table 1). The Colonial Office recruited proportionately more professionals and skilled people than labourers, reflecting needs created in the Colonies by the local labour market and economics, and (importantly) by the toll of disease among expatriates. It is not surprising therefore, that Africa, and especially Nigeria and other West African colonies, should have been the destination of nearly 80 per cent of those Manson examined, the rest going to colonies in Asia, the Americas, and elsewhere (Appendix, Table 2). The 35 women in the sample comprised 10 school teachers and 25 nurses; it is noteworthy that six of the nurses were assigned in 1902 for service in the notorious concentration camps developed by the British in South Africa to confine women and children during the Boer War.

Manson rejected 38 ( 9.2 per cent) of his 413 first-time applicants: eight for suspected alcoholism, seven for albuminuria, four for bad teeth, and the rest for sundry other medical reasons ranging from severe myopia to syphilis. Of the 82 Service personnel on leave or invalided home, Manson disqualified 20 (24.4 per cent) from returning to the tropics, and the diagnoses now included dysentery (two), neurologic problems (five), and blackwater fever or malaria (two). Notice that the rejection rate among returnees, not unexpectedly, was 2.5 times that among the new recruits. Many of those Manson "passed" (his word) for service he required to be revaccinated, and a few even needed primaries.

As a footnote to Manson's clinical data, it may be said that dental problems, not usually considered "tropical diseases", were in reality a continuing subject of discussion by the Colonial Office's Advisory Medical and Sanitary Committee for Tropical Africa. Typical was a letter Manson sent to the Colonial Office in response to complaints about dental problems in Northern Nigeria: ${ }^{18}$

I beg to state that I examine the teeth of every candidate sent me by the Crown Agents and Colonial Office, and in those cases in which I consider the denture inadequate or very likely to give rise to serious trouble I instruct the candidate to have the teeth attended to before sailing. Unfortunately the teeth are bad in at least 90 per

${ }^{18}$ Manson to Colonial Office, 4 November 1908, Ibid., 36356, p. 56. 


\section{Sir Patrick Manson}

cent. of the candidates for subordinate offices, such as railway surfacemen, and the men poor and unable to furnish themselves with plates or have their decayed teeth properly stopped [filled]. To reject these would amount to almost wholesale rejection of all men of their class. I therefore pass the best, recommending plates, etc., when absolutely necessary, and reject the worst. I have to use my judgement in these respects, and do what I consider to be best in the interest of the Crown Agents. If all cases of bad teeth were rejected, very few would pass. It has often occurred to me that it would pay Government to employ a dentist who, for a low fee such as these men could afford, would put their mouths in order before they leave England.

The Colonial Office consulted Manson on a wide range of other health-related technical matters: safe shipment of smallpox vaccine, specifications for anti-mosquito screening, rat poisons, contraptions for fumigating ships and the inside of mosquito nets, stipulations for the use of quinine, and the like. Manson, however, probably made his greatest individual contributions to policy during Chamberlain's time, i.e., up to 1903; thereafter his influence may have been felt more as a committee member rather than at the ear of the Secretary of State (of whom there were four between Chamberlain's departure from the Colonial Office in 1903 and Manson's in 1912). Committees, incidentally, staffed by external medical-scientific consultants and exercising a measure of power, were an innovation in the Colonial Office at the turn of the century, ${ }^{19}$ and Manson served on all the major Colonial Office committees until his retirement. $^{20}$

\section{MANSON RESIGNS AS MEDICAL ADVISER}

Because of age and infirmity, Manson decided early in 1912 to retire from his practice and resign from the Colonial Office; he had by then moved from his home of twenty years in Queen Anne Street to a residence in nearby Welbeck Street. ${ }^{21}$ Approaching retirement, Manson felt impelled to express some serious concerns to Herbert J. Read (later Sir Herbert), a highly-placed civil servant in the Colonial Office, who had facilitated Manson's appointment fifteen years earlier. Manson's letter to Read explained that ${ }^{22}$

As I told you the other day I feel that I ought to retire from active life. I am in my sixty-eighth year and very easily knocked up. I am afraid I am a permanent cripple and that next attack of gout will floor me altogether. In the public interest as well as in my own I am of opinion that I should tender my resignation of the Medical Advisership to the Colonial Office some time this year-certainly before the end of October. I feel I cannot face another winter in London. I do not wish to leave the Colonial Office in the lurch and moreover there are one or two things I wish to do before I lose the power of locomotion altogether. I would like your friendly guidance about one or two matters.

\footnotetext{
${ }^{19}$ Worboys, op. cit. note 12 above, p. 91.

${ }^{20}$ Manson's Colonial Office Committee appointments included the Advisory Medical and Sanitary Committee for Tropical Africa, the Advisory Committee for the Tropical Disease Fund, the Sleeping Sickness Bureau, and the Entomological Research Committee. See Anderson, op. cit. note 13 above.

${ }^{21}$ In 1985 the Greater London Council placed a blue commemorative plaque on Manson's transient Welbeck Street residence (his former Queen Anne Street house had been razed), and placed another honouring Ronald Ross on his former house nearby in Cavendish Square. See: Trans. Roy. Soc. Trop. Med. Hyg., 1985, 79: 656 .

${ }_{22}$ Manson to Herbert J. Read, 14 February 1912, CO 323/605, pp. 233-6.
} 


\section{Eli Chernin}

Two considerations make me doubtful as to the exact time at which I ought to send in my resignation, namely, the convenience of the Colonial Office and the interests of the School of Tropical Medicine. As regards the former the Colonial Office can decide; as regards the latter I would like to say a word or two to you in confidence.

Because the interests of the London School and of the Colonial Office were intertwined, the letter continued, Manson thought that his successor as Medical Adviser should also be a member of the School and have a practice in tropical diseases. Manson hoped that C. W. Daniels would fill the office; Daniels had served for several years as Director of the London School, continued on its staff, and had extensive experience of tropical diseases. Read was not, however, enthused by the Daniels suggestion. As to the name Read had brought forward in their conversation, that of the eminent clinician, Sir John Rose Bradford, Manson wrote that "he is all that could be wished for as regards professional standing, character and ability... But he lacks practical experience of tropical diseases and ... he is not connected with the Tropical School." Manson therefore suggested in the same letter a compromise: that the Colonial Office name Bradford as Senior Adviser to examine all candidates entering service, and Daniels as Junior Adviser, to examine those invalided from the tropics.

Read sent a long minute to Sir George V. Fiddes, Assistant Under Secretary, explaining that "Sir P. Manson is a difficult man to replace, as he occupies an almost unique position as an investigator, possesses a practical knowledge of tropical medicine ... and is an impressive personality." Read did not think Daniels a worthy successor to Manson and favoured Bradford, and he was "not much in love" with Manson's suggestion for a double appointment. Read did not, furthermore, share Manson's concern about an "outsider" prejudicing the future of the London School, asserting that "the School was safe in our hands and that it was not likely that we should allow an organization which we had taken such pains to build up to be lightly destroyed". 23

After further discussions within the Colonial Office and another talk with Manson, Read concluded that since neither of them could suggest "a man combining all the necessary qualifications... I see nothing for it but to accept [Manson's] compromise", 24 a conclusion shared by other senior officials in the Colonial Office. A few days later the Secretary of State for the Colonies, Lewis Harcourt, wrote to Manson to express his regrets at Manson's pending retirement, his thanks for Manson's services, and his inclination to adopt Manson's compromise about his successors. ${ }^{25}$ With Manson's resignation set to become effective in October 1912, Harcourt offered the senior and junior posts to Bradford and Daniels, respectively, outlining their duties and fees as examiners and asking them to keep the appointments in confidence.

On 7 June 1912 Manson wrote in a painful hand from his fishing lodge in Ireland to inform the Colonial Office that ". . . in consequence of the unsatisfactory state of my

${ }^{23}$ H. J. Read, minute, to Sir G[eorge] V. Fiddes, undated but probably 15-16 February 1912, CO $323 / 605$, pp. 229-30. $230-1$.

${ }^{24}$ H. J. Read to Sir John Anderson [Permanent Under Secretary], 29 February 1912, CO 323/605, pp.

${ }^{25}$ L. Harcourt to Manson, 2 March 1912, CO 335/605, pp. 237-8. 


\section{Sir Patrick Manson}

health I am constrained to tender my resignation of my office of Medical Adviser . . . and to request that my resignation take effect from the 15th of August. .."26 The public and medical press were informed on 12 July, and on $15 \mathrm{July}$ Harcourt notified all Colonial Governments of Manson's impending resignation, and that his duties as Medical Adviser were to be divided between Bradford and Daniels. ${ }^{27}$ On 15 August 1912, his last day as Medical Adviser, Manson, in a final gesture of responsibility, informed the Colonial Office that "all registers and papers connected with [the Colonial Office] have been handed by me to Dr. C. W. Daniels". ${ }^{28}$ This transfer to Daniels, long affiliated with the London School, probably explains how Manson's casebooks came into that institution.

\section{COMMENTS}

Manson's clinical work under the terms of his appointment as Medical Adviser throws new light on his association with the Colonial Office. The conventional notion, adopted or implied by most writers, that Manson advised solely on matters of policy is mistaken. Manson's letter of appointment, it will be recalled, and those of his two successors, stipulated clinical responsibilities and nothing else. It appears that Manson early on created a special role for himself that served Chamberlain's purposes as well. Obviously the personal relationship between Manson and Chamberlain must have been favourable and the times propitious, for no other Medical Adviser before or after Manson seems to have played a similar role. It is worth notice that in his public posts, in the Customs Service in China and at the Colonial Office, Manson's primary responsibilities were clinical. Yet from his clinical base he managed in China to make his most important scientific discoveries, ${ }^{29}$ and in London his clinical connection helped forward important policy initiatives in the Colonial Office. As the acknowledged father of modern tropical medicine, Manson was many men, but at root he was a dedicated and experienced physician, who, serving the Colonial Office, found himself concerned with what now would be called "occupational health", and with selecting people for their fitness to serve in unhealthy places. It was no exaggeration that the White Man's Grave awaited many in West Africa, and thus no surprise that a popular jingle of the day ran, "Beware and betide the Bight of Benin/For few come out though many go in."

Manson's status was such that he could successfully arrange at retirement to protect his perceived interests in the London School, then as now his prime academic offspring. It says much about Manson that two men were required as Medical Advisers to handle the job Manson/ had done alone. It is also interesting that, while the search was on for Manson's successor, Harcourt should have mused in an internal minute: "I suppose Sir R. Ross is permanently attached to Liverpool [the School of Tropical

\footnotetext{
${ }^{26}$ Manson to the Under Secretary of State, [2 or 7] June 1912, CO 323/605/17978, pp. 244-5.

${ }^{27}$ L. Harcourt to Colonial Governments, 15 July 1912, CO 323/605, p. 73. The circular notice also carried word of W. T. Prout's appointment as Medical Adviser in Liverpool (see also note 30).

${ }^{28}$ Manson to Under Secretary of State, 15 August 1912, CO 323/605/25885, p. 303. The papers of civil servants were the property of Government, but advisers and consultants (except lawyers) could retain theirs upon leaving service.

${ }^{29}$ Chernin, op. cit., note 10 above.
} 


\section{Eli Chernin}

Medicine] and could not be tempted to London." ${ }^{30}$ Ross was in fact planning to leave Liverpool (he resigned late in 1912) to set up a consulting practice in London, and he would almost certainly have been interested in a tender for Manson's post. From the time Manson first mooted his resignation to the point at which the news was made public - some five months - no word of it apparently reached Ross, although he had contacts in the Colonial Office. Because Manson and Ross were not on friendly terms by then, and because Ross's clinical skills had been questioned by some, pains may have been taken to suppress word of the forthcoming vacancy. ${ }^{31}$ Manson's position in the Colonial Office obviously carried prestige and monetary return, both of which Ross was known to prize. ${ }^{32}$

Manson was knighted in 1903, and, on his retirement in 1912, he received the Grand Cross of the Order of St Michael and St George (G.C.M.G.) "in recognition of eminent services in connexion with the investigation of the causes and cures of tropical diseases". ${ }^{33}$ Appropriately enough, the Chancery of that high Order of Chivalry was housed in the Colonial Office.

${ }^{30}$ L. Harcourt, minute, 2 March 1912, CO 323/605, p. 242. Apparently no one in the Colonial Office chose to follow up on Harcourt's minute, perhaps because Ronald Ross was not entirely admired in the Office precincts. There was also concern in the Colonial Office over the delay of several months before announcing Manson's retirement and his successors' appointments, but the Office obliged Manson who claimed that his practice would suffer "if word got out prematurely" (H. J. Read, minute, 26 March 1912, CO 335/605). Manson's stated concern over his practice during its terminal months seems unconvincing, and while his true motives for delaying the announcement can only be guessed at, they may have reflected the soured relationship between himself and Ross.

${ }^{31}$ Professional relations between Ross and Manson apparently began to deteriorate soon after Ross joined the Liverpool School (M. Worboys, 'Manson, Ross, and colonial medical policy ... 1899-1914', in R. Macleod and M. Lewis (eds), Disease, medicine, and empire, London, Routledge, 1988. The problems became overt when, soon after Manson's retirement, Ross threatened to sue him for libel over a remark Manson had made about Ross's clinical teaching in a letter supporting W. T. Prout, then a candidate to replace the departing Ross as Professor in the Liverpool School of Tropical Medicine. Any further association between the two men became impossible. See: E. Chernin, 'Sir Ronald Ross vs. Sir Patrick Manson, a matter of libel', J. Hist. Med. Allied Sci., 1988, 43: 262-74.

${ }_{32}$ E. Chernin, 'Sir Ronald Ross, malaria, and the rewards of research', Med. Hist., 1988, 32: $119-41$.

${ }^{33}$ Manson-Bahr and Alcock, op. cit. note 3 above, p. 245. 


\section{APPENDIX}

Table 1: OCCUPATIONS OF THE SAMPLE OF 500 PERSONS EXAMINED BY MANSON. RANKED IN DESCENDING ORDER OF FREQUENCY

Occupations

Engineers

(Civil, mechanical, electrical, etc.)

Railway workers

(Locomotive drivers, platelayers, fitters, etc.)

Health personnel

(Medical officers and nurses [25])

Administrators

(Inspectors, judges, superintendents, etc.)

Miscellaneous

(Accountants, draughtsmen, shipmasters, etc.)

Foremen

(Railways, roads, works, etc.)

Other professionals

(Barristers, surveyors, clerics, etc.)

Police force

(Policemen, detectives, prison wardens, etc.)

Military

(Mostly West African Frontier Forces)

Clerks

Labourers and artisans

(Carpenters, blacksmiths, bricklayers, etc.)

Educators

No data

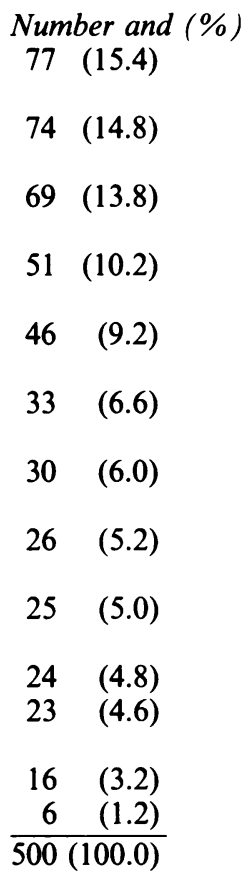

Table 2: DESTINATIONS OR ORIGINS OF A SAMPLE OF 500 PERSONS MANSON EXAMINED FOR THE COLONIAL OFFICE

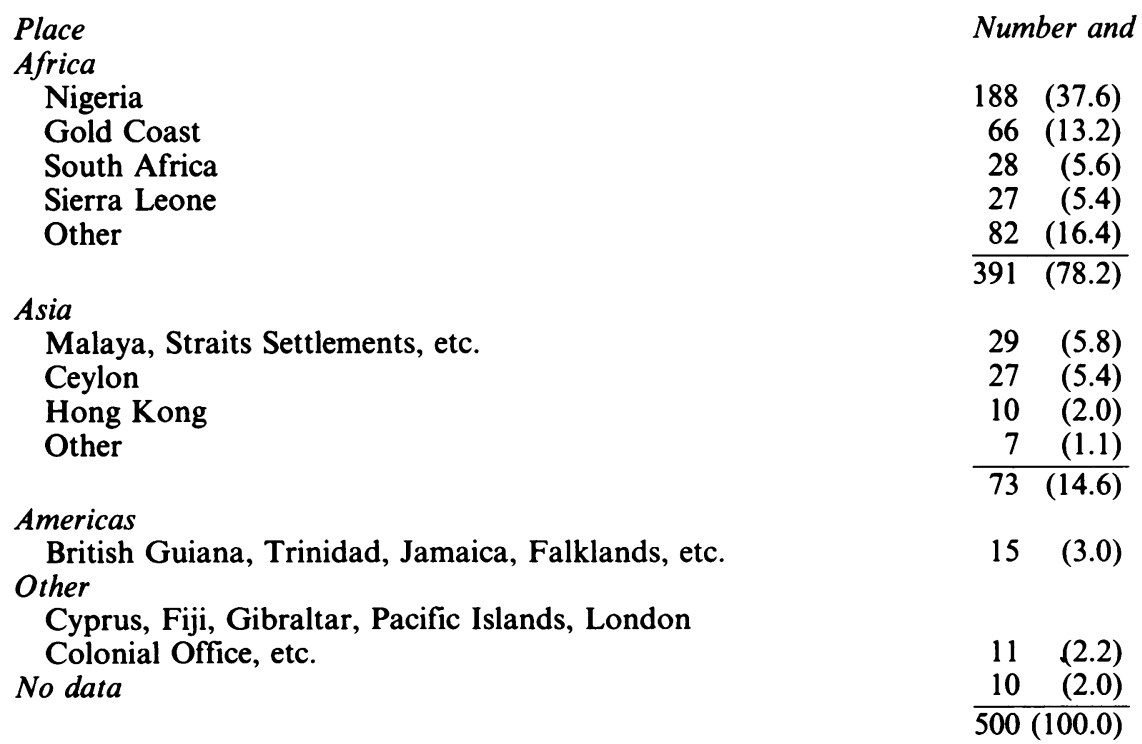

